\title{
Information as a Morpho-Ontological Process ${ }^{\dagger}$
}

\author{
Jordi Vallverdú \\ Philosophy Department, Universidad Autònoma de Barcelona, 08193 Barcelona, Spain; \\ jordi.vallverdu@uab.cat; Tel.: +34-581-16-18 \\ + Presented at the IS4SI 2017 Summit DIGITALISATION FOR A SUSTAINABLE SOCIETY, Gothenburg, \\ Sweden, 12-16 June 2017.
}

Published: 8 June 2017

\begin{abstract}
The debate about information is clearly ontological: how do we know what is real? Which is the object of our knowledge? Only after having clarified this point we can start epistemological debates, which at their turn, are part of the ontological perspective (about nature, knowledge, and the world itself, here the vicious circle). Therefore: things do not happen in the world, but happen in our minds. For that reason, information cannot be considered something real that is just expecting to be captured by some information-gatherer entity like a human being. At that point the multidimensional aspects related to information integration produced by some special entities, which at their turn are constrained by specific morphological aspects, reveal the conflictive nature of reality as information. In fact, it is a process.
\end{abstract}

Keywords: information; morpho-ontological; Eastern; Western; process; multidimensional; holism; discretization

Two monks were watching a flag flapping in the wind.

One said to the other, "The flag is moving."

The other replied, "The wind is moving."

Huineng overheard this.

He said, "Not the flag, not the wind; mind is moving."

\section{Introduction: Information as a Vicious Circle, or a Tautology}

The introductory quoted text can be found listed as \#29 into a 13th century compilation of Zen koans, made by Chinese Zen master Wumen Huikai. Such compilation was titled The Gateless Gate (Mandarin: 無門關 Wúménguān; Japanese: 無門関 Mumonkan) and has had a deep impact into East thinkers since then. The debate is clearly ontological: how do we know what is real? Which is the object of our knowledge? Only after having clarified this point we can start epistemological debates, which at their turn, are part of the ontological perspective (about nature, knowledge, and the world itself, here the vicious circle). The quoted koan is famous because point to the crucial question: things do not happen in the world (or we would be facing a tautology: "this world is this world"), but happen in our minds. Our thoughts are surrogates of other entities and at the same time a new kind of reality. For that reason, information cannot be considered something real that is just expecting to be captured by some information-gatherer entity like a human being. For such reason, it makes not either sense to establish clear differences between data or meta-data, as if informational properties were hierarchically differentiated as well as belong to a static moment of the universe.

\section{The Information Idea and Some Transdisciplinary Problems}

Obviously this short text will not solve the several debates about the meaning and interpretation of "information", as it could be considered outrageous or chimeric by some expert readers. Anyhow, we can make an interesting exercise: what does explain us the fact that there are so 
many ideas about the meaning of information? The reason is simple: classic approaches to the raw and purest aspects of reality are not universal, or even functional. Take for example, our knowledge about biological nature as is being debated at synthetic biology multidisciplinary communities [1]: living entities operate on a constant flow and combination of layers of biological mechanisms, something well explained by systems biology [2]. Any mono-disciplinary or static approach only produces bad and conflictive models about the nature of life [3]. The key aspect is to identify the informational identification process as a local, limited and partial approach to the whole universe. Discretization is our necessity, and the extent of some events is only constrained by the economy of our perceptive or conceptual models: it explains the abandon of causality in epidemiological debates in favour of the notion of 'determinant' [4], which is more delicate as well as embedded of statistical reasoning.

For such evident reasons we are attending to the deflation of naïve realism $[5,6]$, that also makes possible the redefinition of the limits of reality. It also enables us the defense of the status of computational simulations as true experiments [7] and the renegotiation of the notion of information.

\section{The Ontologies of the Morphologies and the Temporal Variable}

Obviously, there is a background informational structure that can be known but only as a temporal process and being constrained by the morpho-ontology of the information-gatherer entity. By morpho-ontology I mean the physical conditions that act as a filter for the cognitive process together with the cultural perspective that makes possible the conceptualization of that information. Thus we can find cultural values that affect cognitive processes [8], as well as shape the way by which we look at the informational universe. Take for example the dichotomies between Eastern and Western Thoughts [9,10]:

\begin{tabular}{cc}
\hline Western & Eastern \\
\hline Discretization & Holism \\
Permanence & Impermanence \\
Being & Nothingness \\
$\mathrm{Me}$ & Illusion of identity \\
\hline
\end{tabular}

The ontological approach determines how we approach to the word as able to prove some affordable informative values or not. I remark again that the temporal value is deeply related to the informational morphological structure of the observer: $\mathrm{H}_{2} \mathrm{O}$, for example is not a continuously stable chemical molecule, but their molecular bonds are broken every 1-20 picoseconds, a very short lifetime [11]. Quoting [1] we can affirm that even the most established of chemical models, $\mathrm{H}_{2} \mathrm{O}$, is oversimplified. The reason for water properties such as freezing and conductivity is that every water molecule is hydrogen bonded with up to four other water molecules, creating a large dynamic net of hydrogen bonds. The central dogma and $\mathrm{H}_{2} \mathrm{O}$ are convenient temporary scaffolds to frame our thought process as we attempt to understand the world we live in. As Bernard le Bovier de Fontenelle wrote in 1686, Entretiens sur la pluralité des mondes:

“Si les roses, qui ne durent qu'un jour, faisaient des histoires, et se laissent des mémoires les unes aux autres, les premières auraient fait le portrait de leur jardinier d'une certaine façon et, de plus de quinze mille âges de roses, les autres qui l'auraient encore laissé à celles qui les devaient suivre, n'y auraient rien changé. Sur cela, elles diraient: Nous avons toujours vu le meme jardinier, de mémoire de rose on n'a vu que lui, il a toujours été fait comme il est, assurément il ne meurt point comme nous, il ne change seulement pas. Le raisonnement des roses serait-il bon ?"

...in a nutshell "For The Roses, The Gardener Is Eternal". The difference is that we know that we are wrong about the informational values we perceive, and try to combine parts of them with some external aid: computer tools. Finally, we must to take into account that our personal and/or social 
emotional states also affect the way by which we capture, process, evaluate and select informational values $[12,13]$.

\section{End Remarks and Some Corollaries for AI Cognitive Approaches}

As a final remark I want to select some related ideas about the nature of informational values: time, morpho-ontology, coupling coherence between data and expectations and then a data integration/binding/blending which is at the same time a multi-dimensional and evolvable and dynamic multi-heuristic process [14]. If we add the use of external intelligent systems that help us with the processing, analysis and even pattern discoveries among those new data-tsunamis, we are facing a cognitive externalization, the profusion of more and more black boxes, approximated mathematical proofs and a universe of data beyond our capacities [15]. Disambiguation is not so clear. The limits of our thoughts are now the limits of what AI can explain us in a way we can understand. Information is then an (unsupervised) process, not a fact.

Acknowledgments: This research has been funded by DGICYT project (2015-2017): Creatividad, revoluciones e innovación en los procesos de cambio científico (FFI2014-52214-P). Head: Anna Estany.

Conflicts of Interest: The authors declare no conflict of interest

\section{References}

1. Gustafsson, C.; Vallverdú, J. The Best Model of a Cat Is Several Cats. Trends Biotechnol. 2016, 34, 207-213.

2. Kitano, H. Systems Biology: A Brief Overview. Science 2002, 295, 1662-1664.

3. Vallverdú, J.; Gustafsson, C. Synthetic Life: Ethobricks for a New Biology. In Systems Biology and Synthetic Biology; John Wiley \& Sons, Inc.: Hoboken, NJ, USA, 2009; pp. 273-285.

4. Vallverdú, J. Bayesians Versus Frequentists; Springer: Berlin/Heidelberg, Germany, 2016.

5. Kennedy, M. Naïve realism, privileged access, and epistemic safety. Nous 2011, 45, 77-102.

6. Conduct, M.D. Naïve realism and extreme disjunctivism. Philos. Explor. 2010, 13, 201-221.

7. Vallverdú, J. What are Simulations? An Epistemological Approach. Procedia Technol. 2014, 13, 6-15.

8. Nisbet, R.E. The Geography of Thought: How Asians and Westerners Think Differently...and Why; Nisbett, R.E., Ed.; Amazon.com, Books: Seattle, WA, USA; Free Press (Simon \& Schuster, Inc.): New York, NY, USA, 2003; ISBN 9780743255356

9. Heisig, J.W. Philosophers of Nothingness: An Essay on the Kyoto School; University of Hawai'i Press: Honolulu, HI, USA, 2001.

10. Weinmayr, E. Thinking in Transition: Nishida Kitarō and Martin Heidegger. Philos. East West 2005, 55, 232-256.

11. Keutsch, F.N.; Saykally, R.J. Water clusters: Untangling the mysteries of the liquid, one molecule at a time. Proc. Natl. Acad. Sci. USA 2001, 98, 10533-10540.

12. Jiménez-Ortega, L.; Martín-Loeches, M.; Casado, P.; Sel, A.; Fondevila, S.; de Tejada, P.H.; Schacht, A.; Sommer, W. How the Emotional Content of Discourse Affects Language Comprehension. PLoS ONE 2012, 7, e33718.

13. Ferrara, E.; Yang, Z. Measuring Emotional Contagion in Social Media. PLoS ONE 2015, 10, e0142390.

14. Vallverdu, J. Re-embodying cognition with the same 'biases'? Int. J. Eng. Future Technol. 2018, 15, 23-31.

15. Casacuberta, D.; Vallverdú, J. E-science and the data deluge. Philos. Psychol. 2014, 27, 126-140.

(C) 2017 by the authors. Licensee MDPI, Basel, Switzerland. This article is an open access article distributed under the terms and conditions of the Creative Commons Attribution (CC BY) license (http://creativecommons.org/licenses/by/4.0/). 